\author{
Katarzyna Frodyma \\ Katedra Statystyki \\ Uniwersytet Ekonomiczny w Krakowie
}

\title{
Rynek energii ze źródel odnawialnych w Unii Europejskiej - analiza statystyczna
}

\section{Streszczenie}

Dynamiczny rozwój cywilizacyjny wiąże się z rosnącym zapotrzebowaniem na energię. Wykorzystywanie tradycyjnych źródeł energii, takich jak węgiel, ropa naftowa i gaz ziemny, wiąże się nie tylko ze wzrostem zanieczyszczenia środowiska, ale powoduje także wyczerpywanie się zasobów naturalnych. Alternatywę dla nieodnawialnych nośników energii, jakimi są paliwa kopalniane, stanowią odnawialne źródła energii.

Głównym celem artykułu jest ocena zmian zachodzących na rynku energii ze źródeł odnawialnych w Unii Europejskiej. Na podstawie tych dostępnych danych przeprowadzono liniowe uporządkowanie krajów ze względu na udział energii ze źródeł odnawialnych w produkcji energii elektrycznej. Omówione zostały zmiany w strukturze produkcji energii ze źródeł odnawialnych. Kraje podzielono na grupy ze względu na strukturę produkcji energii ze źródeł odnawialnych.

Słowa kluczowe: energia ze źródeł odnawialnych, porządkowanie liniowe, grupowanie, współczynnik tau-Kendalla, miara Randa.

\section{Wprowadzenie}

Dynamiczny rozwój cywilizacyjny, który obecnie ma miejsce, wiąże się z rosnącym zapotrzebowaniem na energię. Wykorzystywanie tradycyjnych źródeł energii, takich jak węgiel, ropa naftowa i gaz ziemny, związane jest nie tylko ze wzrostem zanieczyszczenia środowiska, ale powoduje także wyczerpywanie się 
zasobów naturalnych. Alternatywę dla nieodnawialnych nośników energii, jakimi są paliwa kopalniane, stanowią odnawialne źródła energii. Statystyka dotycząca energii jest w centrum zainteresowania ze względu na jej strategiczne znaczenie dla zrównoważonego rozwoju gospodarczego. W ostatnich latach w Unii Europejskiej rozważanych jest kilka ważnych kwestii związanymi z energią, takich jak zmienność cen ropy, przerwy w dostawie energii z krajów nienależących do Unii Europejskiej oraz trudności w dostępie do rynku dla dostawców w przypadku gazu i energii elektrycznej. Kwestie te sprawiły, że temat energii stał się jednym z głównych tematów politycznych w krajach europejskich, zaś wykorzystanie odnawialnych źródeł energii jest postrzegane jako kluczowy element polityki energetycznej. W 2009 r. przyjęto pakiet znany jako cel 20-20-20 [Dyrektywa 2009/28/WE z dnia 23 kwietnia 2009 r. ...]. W pakiecie klimatyczno-energetycznym zawarte są następujące cele na rok 2020:

- redukcja emisji gazów cieplarnianych w UE o co najmniej $20 \%$ poniżej poziomu z 1990 r.;

- co najmniej $20 \%$ końcowego zużycia energii brutto w UE ma pochodzić z odnawialnych źródeł energii;

- co najmniej $10 \%$ końcowego zużycia energii transportowych w UE ma pochodzić z odnawialnych źródeł energii;

- zmniejszenie o $20 \%$ zużycia energii pierwotnej w porównaniu z przewidywanymi poziomami; zmniejszenie to ma zostać osiągnięte poprzez poprawę efektywności energetycznej.

Głównym celem badania jest ocena zmian zachodzących na rynku energii ze źródeł odnawialnych w Unii Europejskiej. W niniejszym artykule kraje Unii Europejskiej uporządkowane zostały ze względu na udział energii odnawialnej w produkcji energii elektrycznej. Na podstawie współczynnika tau-Kendalla potwierdzona została hipoteza, że uporządkowania te nie ulegały istotnym zmianom w latach 2004-2012. Następnie państwa Unii Europejskiej pogrupowane zostały ze względu na strukturę produkcji energii elektrycznej z poszczególnych nośników odnawialnych źródeł energii. Grupowanie to przeprowadzone zostało metodą Warda z wykorzystaniem odległości euklidesowej. W celu potwierdzenia hipotezy badawczej, zgodnie z którą wyniki grupowania w latach 2004-2012 nie różnią się między sobą, wykorzystano klasyczną miarę Randa podobieństwa składów klas.

Głównym źródłem danych jest opracowanie Głównego Urzędu Statystycznego Energia ze źródeł odnawialnych w 2012 r. [2013] oraz strona internetowa Eurostatu (http://epp.eurostat.ec.europa.eu, dostęp: 20.04.2014 r.). Wiele artykułów związanych z energią odnawialną znaleźć można w miesięczniku „Energetyka" - m.in. Kierunki polityki energetycznej Polski oraz Unii Europejskiej w latach 2007-2030 [Karpińska i Dul 2014], Energetyka wiatrowa. Aktualne 
trendy rozwoju w Polsce [Badyda 2013] czy Rozproszone źródta energii elektrycznej ze szczególnym uwzględnieniem odnawialnych źródet energii [Czechowicz 2012]. Informacje o nośnikach energii ze źródeł odnawialnych w Polsce i Unii Europejskiej w latach wcześniejszych prezentuje m.in. artykuł Wykorzystanie odnawialnych $i$ nieodnawialnych źródet energii w Polsce $i$ w krajach UE [Sadowski, Świderski i Lewandowski 2008], zaś Energia odnawialna w Polsce w 2012 [2012] to raport przygotowany przez portal Gramwzielone.pl dotyczący nośników energii w Polsce.

\section{Udział energii odnawialnej w końcowym zużyciu energii w latach 2004-2012}

W tabeli 1 zaprezentowano całkowite zużycie energii w tys. ton w przeliczeniu na 1000 mieszkańców w poszczególnych krajach Unii Europejskiej w latach 2004-2012. Największe zużycie energii w przeliczeniu na 1000 mieszkańców odnotowano w Luksemburgu, najmniejsze zaś w Rumunii. Wzrost zużycia w badanym okresie nastąpił tylko w Estonii, na Łotwie i w Polsce. Największy spadek zużycia zaobserwowano m.in. na Cyprze, w Irlandii oraz w Wielkiej Brytanii. W takich krajach jak Austria i Bułgaria w badanym okresie zużycie energii pozostało na niezmienionym poziomie.

Tabela 1. Zużycie energii w tys. ton w przeliczeniu na 1000 mieszkańców w latach 2004-2012

\begin{tabular}{|l|c|c|c|c|c|c|c|c|c|}
\hline \multicolumn{1}{|c|}{ Kraj } & 2004 & 2005 & 2006 & 2007 & 2008 & 2009 & 2010 & 2011 & 2012 \\
\hline Belgia & 5,7 & 5,6 & 5,5 & 5,3 & 5,6 & 5,3 & 5,6 & 5,4 & 5,1 \\
\hline Bułgaria & 2,4 & 2,5 & 2,6 & 2,6 & 2,7 & 2,3 & 2,4 & 2,6 & 2,5 \\
\hline Czechy & 4,5 & 4,4 & 4,5 & 4,5 & 4,4 & 4,1 & 4,3 & 4,1 & 4,1 \\
\hline Dania & 3,7 & 3,6 & 3,9 & 3,8 & 3,7 & 3,5 & 3,6 & 3,4 & 3,3 \\
\hline Niemcy & 4,2 & 4,1 & 4,3 & 4,1 & 4,1 & 3,9 & 4,1 & 3,9 & 3,9 \\
\hline Estonia & 4,1 & 4,1 & 4,1 & 4,6 & 4,4 & 4,0 & 4,6 & 4,7 & 4,6 \\
\hline Irlandia & 3,7 & 3,7 & 3,7 & 3,7 & 3,5 & 3,3 & 3,3 & 3,1 & 3,0 \\
\hline Grecja & 2,8 & 2,8 & 2,8 & 2,8 & 2,8 & 2,7 & 2,6 & 2,5 & 2,4 \\
\hline Hiszpania & 3,3 & 3,3 & 3,3 & 3,3 & 3,1 & 2,8 & 2,8 & 2,7 & 2,7 \\
\hline Francja & 4,4 & 4,4 & 4,3 & 4,2 & 4,2 & 4,0 & 4,1 & 4,0 & 4,0 \\
\hline Chorwacja & 2,0 & 2,1 & 2,1 & 2,2 & 2,1 & 2,0 & 2,0 & 2,0 & 1,9 \\
\hline Włochy & 3,2 & 3,2 & 3,2 & 3,2 & 3,1 & 2,9 & 2,9 & 2,9 & 2,7 \\
\hline Cypr & 3,4 & 3,5 & 3,5 & 3,6 & 3,7 & 3,5 & 3,3 & 3,2 & 2,9 \\
\hline Łotwa & 2,0 & 2,0 & 2,1 & 2,2 & 2,1 & 2,1 & 2,2 & 2,1 & 2,2 \\
\hline Litwa & 2,7 & 2,6 & 2,6 & 2,9 & 2,9 & 2,7 & 2,2 & 2,3 & 2,4 \\
\hline
\end{tabular}


cd. tabeli 1

\begin{tabular}{|l|c|c|c|c|c|c|c|c|c|}
\hline \multicolumn{1}{|c|}{ Kraj } & 2004 & 2005 & 2006 & 2007 & 2008 & 2009 & 2010 & 2011 & 2012 \\
\hline Luksemburg & 10,3 & 10,4 & 10,1 & 9,7 & 9,6 & 8,8 & 9,2 & 8,9 & 8,5 \\
\hline Węgry & 2,6 & 2,7 & 2,7 & 2,7 & 2,7 & 2,5 & 2,6 & 2,5 & 2,4 \\
\hline Malta & 2,3 & 2,4 & 2,3 & 2,4 & 2,4 & 2,1 & 2,3 & 2,2 & 2,2 \\
\hline Holandia & 5,0 & 5,0 & 4,9 & 5,1 & 5,1 & 4,9 & 5,2 & 4,8 & 4,9 \\
\hline Austria & 4,1 & 4,2 & 4,2 & 4,1 & 4,1 & 3,9 & 4,1 & 4,0 & 4,0 \\
\hline Polska & 2,4 & 2,4 & 2,5 & 2,5 & 2,6 & 2,5 & 2,6 & 2,6 & 2,5 \\
\hline Portugalia & 2,6 & 2,6 & 2,5 & 2,5 & 2,4 & 2,4 & 2,3 & 2,2 & 2,1 \\
\hline Rumunia & 1,8 & 1,8 & 1,9 & 1,9 & 2,0 & 1,7 & 1,8 & 1,8 & 1,8 \\
\hline
\end{tabular}

Źródło: obliczenia własne.

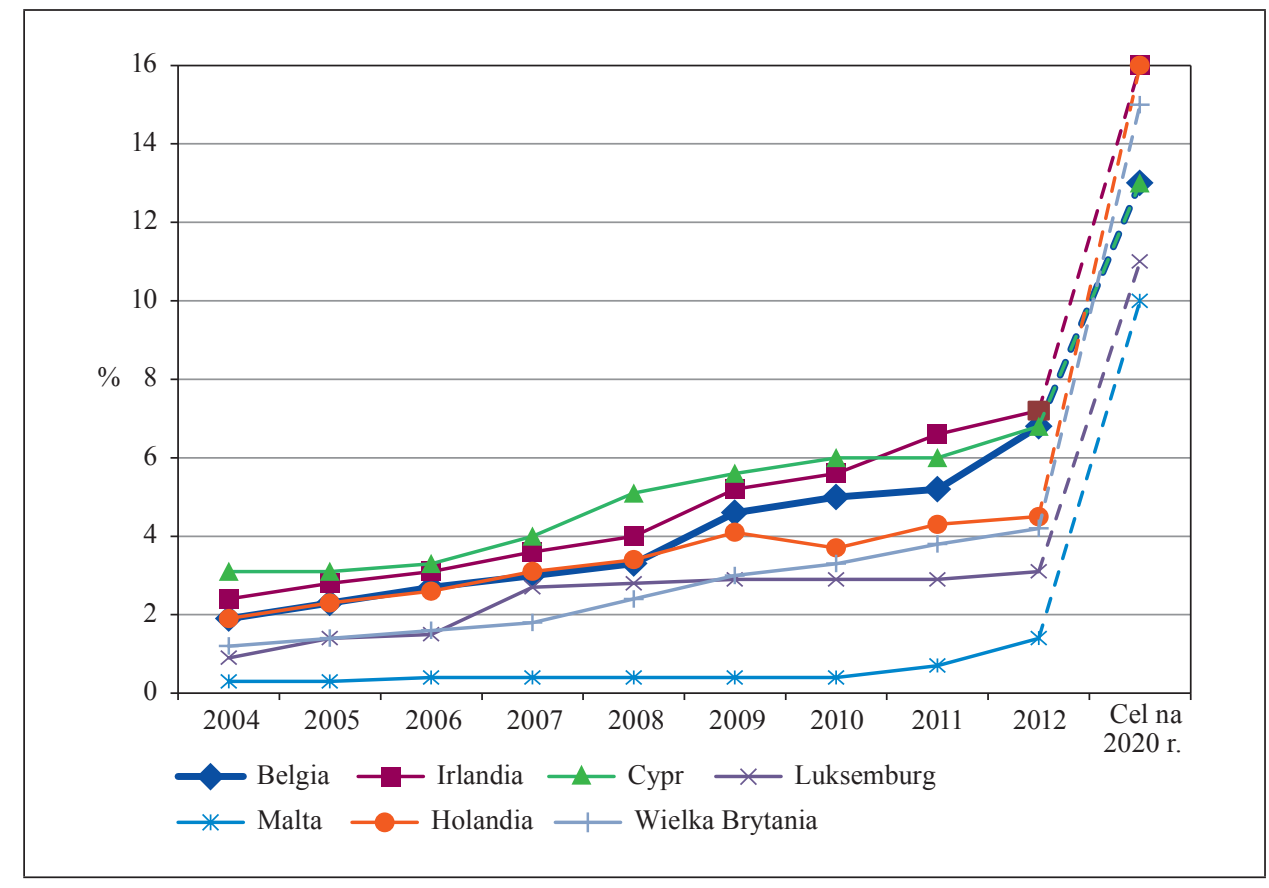

Rys. 1. Kraje Unii Europejskiej charakteryzujące się najniższym udziałem energii ze źródeł odnawialnych w końcowym zużyciu energii (poniżej średniej unijnej) w latach 2004-2012 oraz cel na 2020 r.

Źródło: opracowanie własne.

Jako jeden z celów określonych w pakiecie klimatyczno-energetycznym przyjęto, że co najmniej 20\% końcowego zużycia energii brutto ma pochodzić 
z odnawialnych źródeł energii, przy czym w każdym z krajów Unii Europejskiej udział ten ma być na innym poziomie. Jak wynika z rys. 1-3, różny jest udział odnawialnych źródeł energii w końcowym zużyciu energii w poszczególnych krajach. Średnia dla Unii Europejskiej w 2012 r. wyniosła 16,85\%, mediana miała wartość $13,90 \%$, a rozkład był prawostronnie asymetryczny (współczynnik asymetrii ${ }^{1}$ wyniósł 1,12 ), co oznacza, że większość krajów charakteryzowała się niższym udziałem, niż wynosi średnia.

Na podstawie rys. 1 można stwierdzić, że najwięcej do zrealizowania zamierzonego celu zawartego w dyrektywie z 2009 r. brakuje Holandii (cel - 16,0\%; w 2012 r. - 4,5\%) oraz Wielkiej Brytanii (cel - 15,0\%; w 2012 r. - 4,2\%).

Na rys. 2 zaprezentowane są kraje, których cel jest zbliżony do ogólnego celu dla Unii Europejskiej. Wśród tych krajów najmniej do realizacji celu brakuje Czechom (cel - 13,0\%; w 2012 r. - 11,2\%), zaś najwięcej Hiszpanii (cel - 20,0\%; w 2012 r. - 14,3\%).

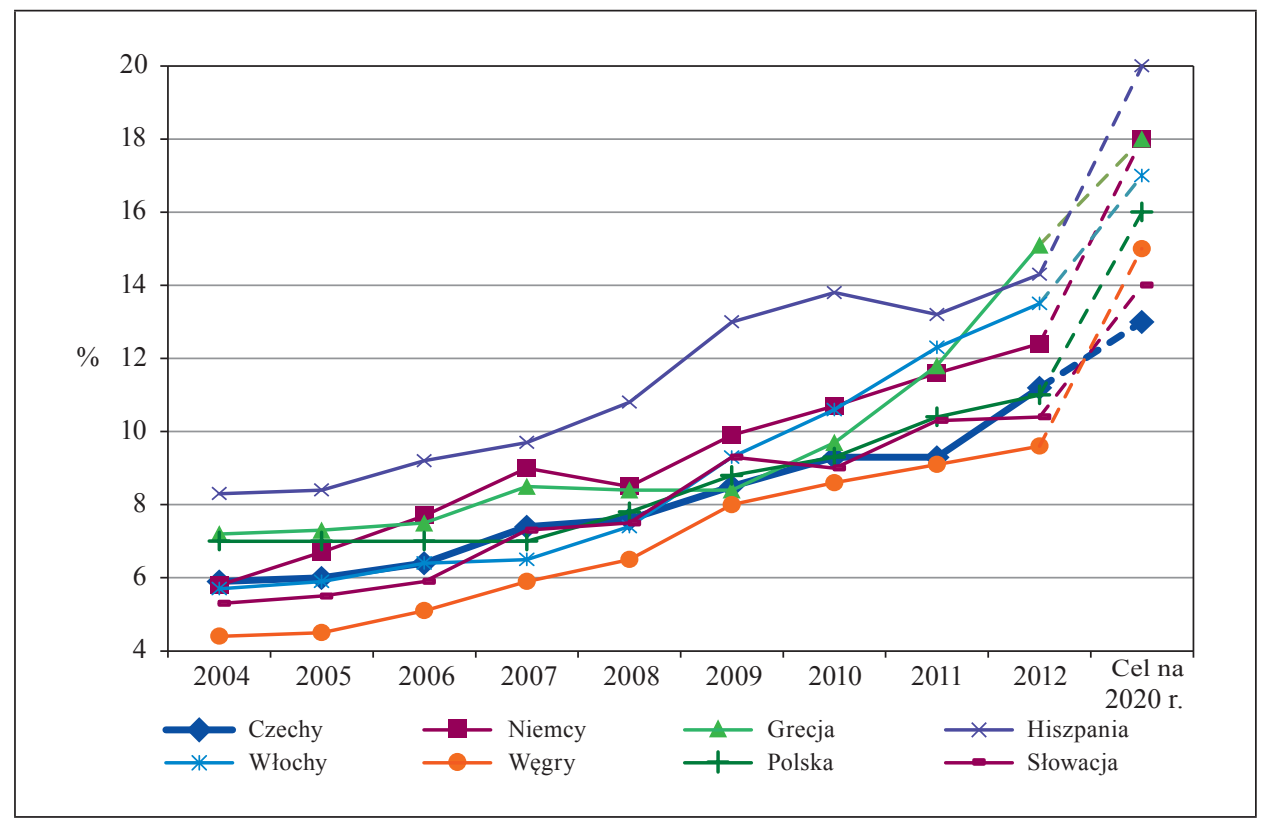

Rys. 2. Kraje Unii Europejskiej charakteryzujące się wyższym udziałem energii ze źródeł odnawialnych w końcowym zużyciu energii (poniżej średniej unijnej) w latach 2004-2012 oraz cel na $2020 \mathrm{r}$.

Źródło: opracowanie własne.

1 Standaryzowany moment centralny rzędu trzeciego. 
Trzy kraje: Bułgaria (cel - 16,0\%; w 2012 r. - 16,3\%), Estonia (cel - 25,0\%; w 2012 r. - 25,2\%) i Szwecja (cel-49,0\%; w 2012 r. - 51,0\%) już w 2012 r. zrealizowały swoje zobowiązania wynikające z pakietu klimatyczno-energetycznego (por. rys. 3).

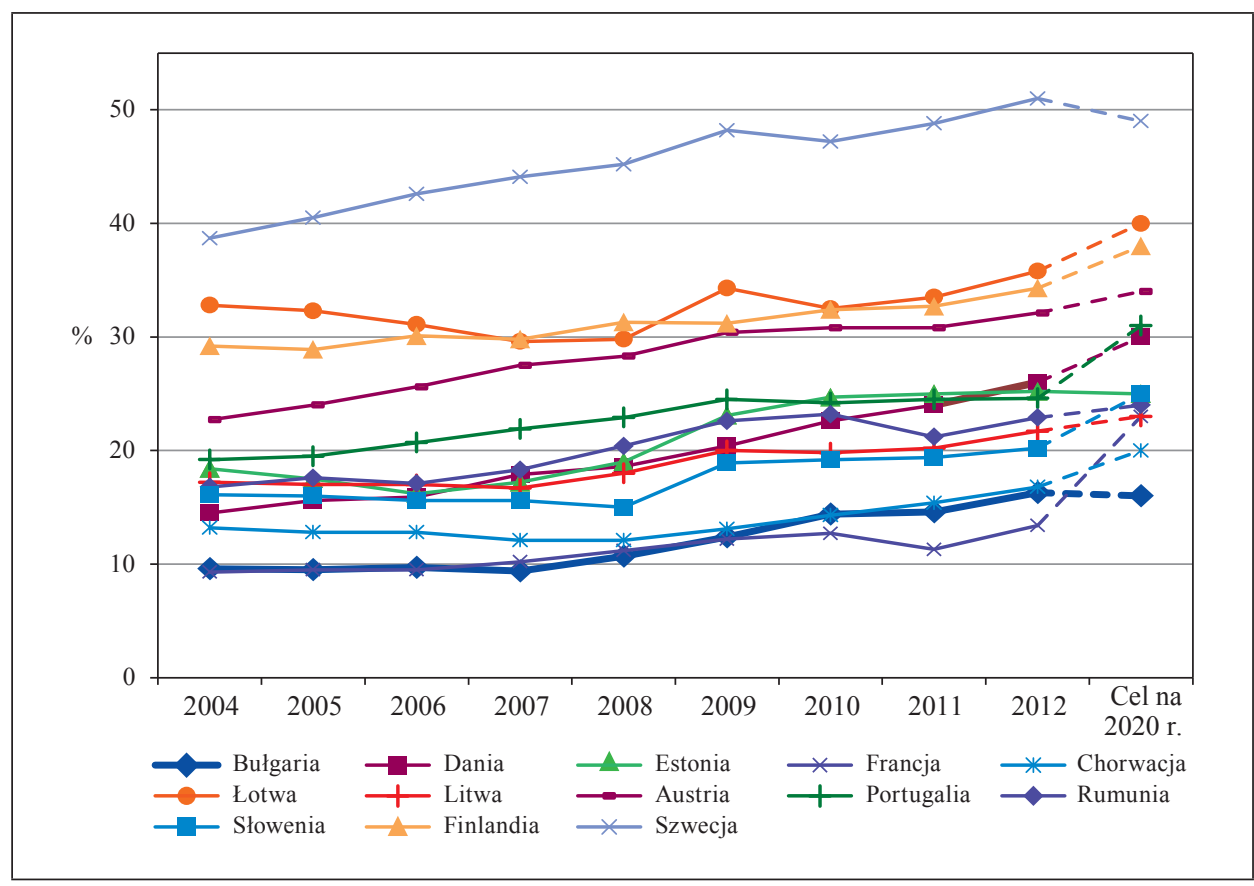

Rys. 3. Kraje Unii Europejskiej charakteryzujące się najwyższym udziałem energii ze źródeł odnawialnych w końcowym zużyciu energii (powyżej średniej unijnej) w latach 2004-2012 oraz cel na $2020 \mathrm{r}$.

Źródło: opracowanie własne.

W celu porównania uporządkowań krajów ze względu na udział energii ze źródeł odnawialnych w końcowym zużyciu energii w kolejnych latach wyznaczono współczynnik tau-Kendalla. W pracy wykorzystany został współczynnik korelacji tau-Kendalla o postaci (zob. [Walesiak 2006]):

$$
\Gamma_{l h}=\frac{\sum_{i=2}^{16} \sum_{k=1}^{i-1} a_{i k l} b_{i k h}}{\left[\sum_{i=2}^{16} \sum_{k=1}^{i-1} a_{i k l}^{2} \sum_{i=2}^{16} \sum_{k=1}^{i-1} b_{i k h}^{2}\right]^{\frac{1}{2}}},
$$


gdzie:

$i, k=1, \ldots, n-$ numer obiektu (kraju),

$l, h$ - numer zmiennej;

z podstawieniem:

$$
a_{i k l}\left(b_{i k h}\right)=\left\{\begin{array}{cccc}
1, & \text { gdy } & x_{i l}>x_{k l} & \left(x_{i h}>x_{k h}\right) \\
0, & \text { gdy } & x_{i l}=x_{k l} & \left(x_{i h}=x_{k h}\right), \\
-1, & \text { gdy } & x_{i l}<x_{k l} & \left(x_{i h}<x_{k h}\right)
\end{array}\right.
$$

gdzie:

$x_{i l}-i$-ta obserwacja dla $l$-tej zmiennej,

$x_{k l}-k$-ta obserwacja dla $l$-tej zmiennej

Współczynnik tau-Kendalla przyjmuje wartości z przedziału $[-1,1]$. Wartość 1 oznacza pełną zgodność uporządkowań, zaś wartość -1 pełną ich przeciwstawność.

Tabela 2. Wartości współczynnika tau-Kendalla

\begin{tabular}{|c|c|c|c|c|c|c|c|c|}
\hline Rok & 2005 & 2006 & 2007 & 2008 & 2009 & 2010 & 2011 & 2012 \\
\hline 2004 & 0,98 & 0,94 & 0,96 & 0,92 & 0,94 & 0,91 & 0,90 & 1,00 \\
\hline 2005 & $\times$ & 0,94 & 0,95 & 0,93 & 0,95 & 0,91 & 0,90 & 0,98 \\
\hline 2006 & $\times$ & $\times$ & 0,98 & 0,91 & 0,91 & 0,87 & 0,88 & 0,94 \\
\hline 2007 & $\times$ & $\times$ & $\times$ & 0,93 & 0,93 & 0,90 & 0,89 & 0,96 \\
\hline 2008 & $\times$ & $\times$ & $\times$ & $\times$ & 0,96 & 0,93 & 0,90 & 0,92 \\
\hline 2009 & $\times$ & $\times$ & $\times$ & $\times$ & $\times$ & 0,95 & 0,93 & 0,94 \\
\hline 2010 & $\times$ & $\times$ & $\times$ & $\times$ & $\times$ & $\times$ & 0,96 & 0,91 \\
\hline 2011 & $\times$ & $\times$ & $\times$ & $\times$ & $\times$ & $\times$ & $\times$ & 0,90 \\
\hline
\end{tabular}

Źródło: obliczenia własne.

Jak wynika $\mathrm{z}$ tabeli 2, uporządkowania w kolejnych latach są niemal identyczne. We wszystkich krajach w badanym okresie obserwowany jest wzrost udziału energii ze źródeł odnawialnych w końcowym zużyciu energii, ale uporządkowania krajów pozostają prawie bez zmian. Co ciekawe, w 2012 r. uporządkowanie państw Unii Europejskiej jest identyczne jak to w 2004 r. (współczynnik tau-Kendalla wynosi 1,00).

Szczegółowe cele polityki energetycznej Polski to wzrost udziału energii ze źródeł odnawialnych w końcowym zużyciu energii do poziomu 15,5\% w $2020 \mathrm{r}$. (19,3\% w przypadku energii elektrycznej, $17 \%$ - ciepłownictwa i chłodnictwa, $10,2 \%$ - paliw transportowych). Na rys. 4 zaprezentowano udział energii z odna- 


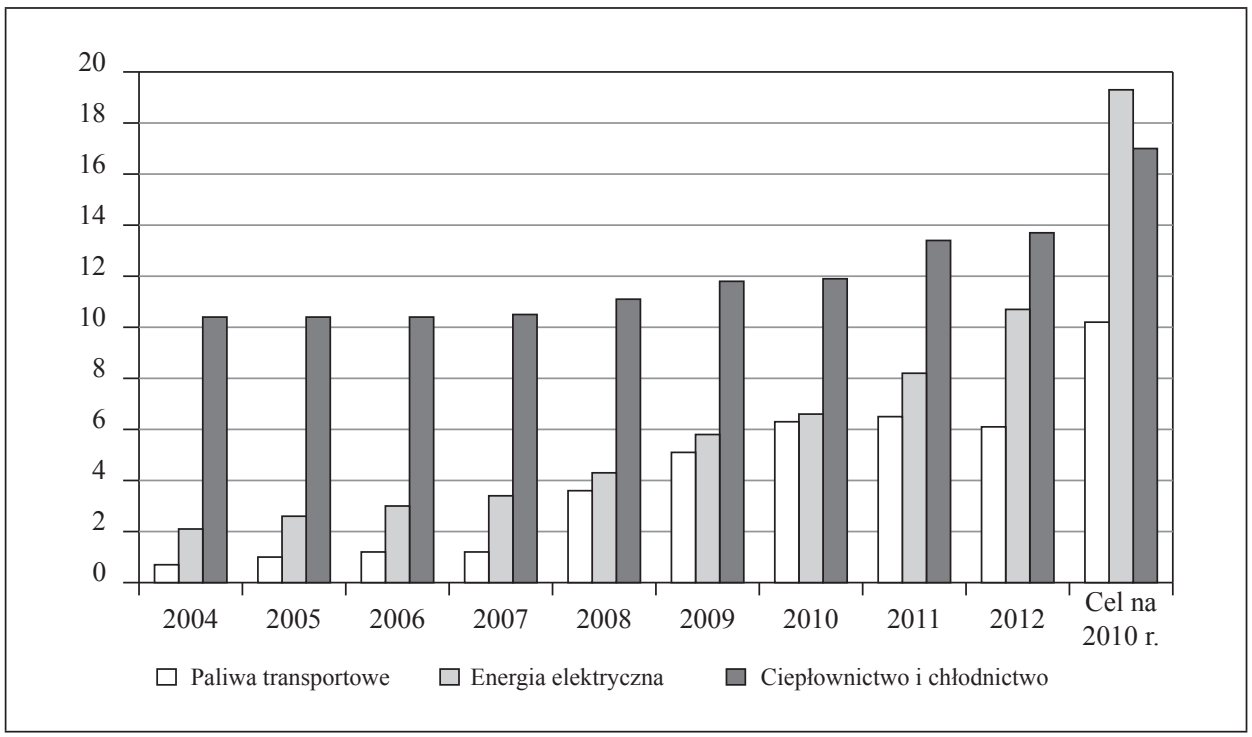

Rys. 4. Udział energii ze źródeł odnawialnych w całkowitym zużyciu energii w Polsce Źródło: opracowanie własne.

wialnych źródeł w całkowitym zużyciu energii w Polsce w latach 2004-2012 w podziale na dziedziny. W największym stopniu udało się zrealizować zobowiązania w zakresie ciepłownictwa i chłodnictwa (brakuje tylko 3,3 pkt proc. do osiągnięcia założonego celu), najgorzej jest w zakresie energii elektrycznej (brakuje jeszcze 8,6 pkt proc., ale wzrost w ciągu 8 lat był w tym przypadku największy i wyniósł 8,8 pkt proc.). W przypadku paliw transportowych do osiągnięcia zamierzonego celu brakuje jeszcze 4,1 pkt proc. Biorąc pod uwagę, że w 2012 r. udział energii ze źródeł odnawialnych w całkowitym zużyciu paliw transportowych wynosił w Polsce 6,1\%, aby cel został osiągnięty, w ciągu kolejnych 8 lat udział ten musi wzrosnąć o ponad 60\% wartości z 2012 r.

\section{Struktura produkcji energii z odnawialnych nośników energii w krajach Unii Europejskiej}

Badając strukturę produkcji energii z odnawialnych nośników energii, zaobserwowano przede wszystkim znaczny wzrost produkcji energii elektrycznej z odnawialnych źródeł energii w latach 2004-2012 (por. rys. 5). Największa część energii ze źródeł odnawialnych pochodzi z biopaliw stałych. 


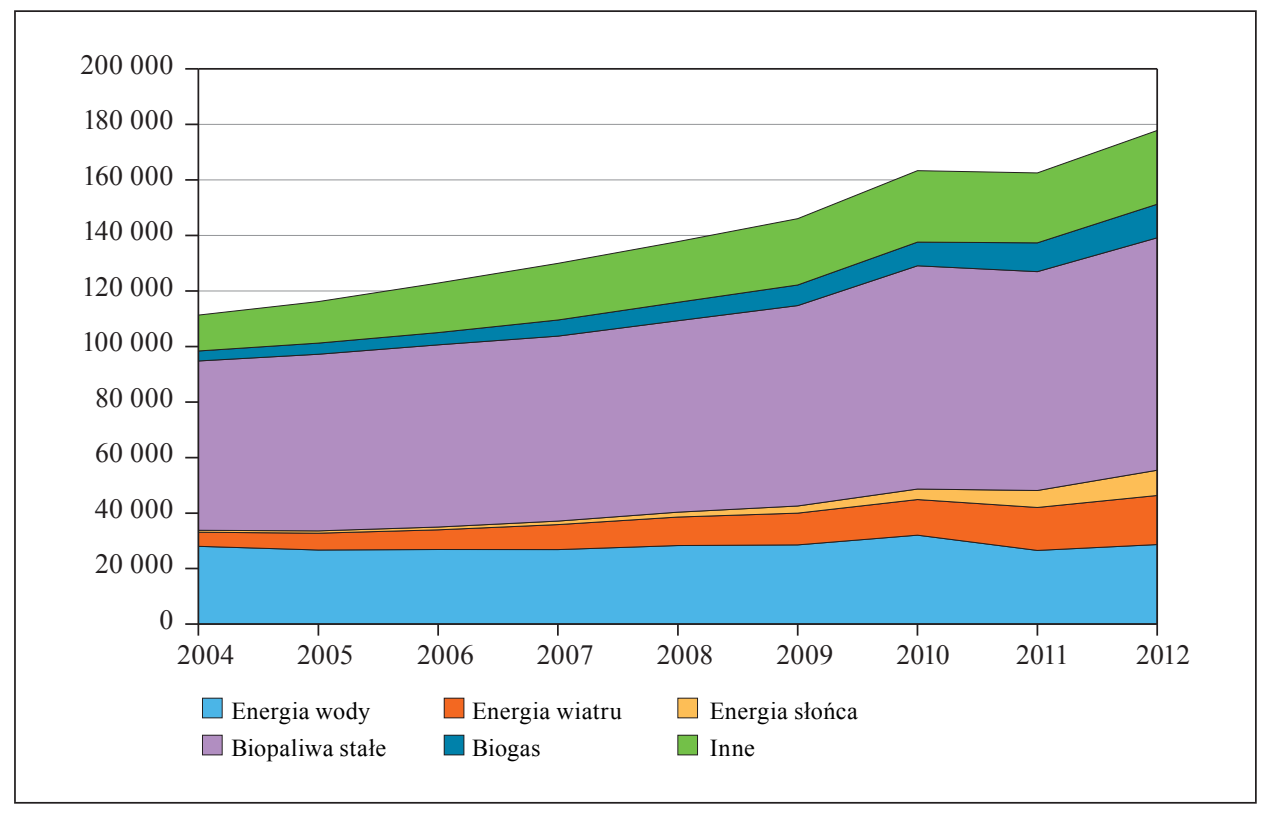

Rys. 5. Nośniki energii ze źródeł odnawialnych w Unii Europejskiej w latach 2004-2012

Źródło: opracowanie własne.

W 2012 r. energia pochodząca z biopaliw stałych stanowiła 47,08\% całkowitej produkcji energii ze źródeł odnawialnych w Unii Europejskiej, ale udział produkcji energii z tego nośnika zmalał w badanym okresie (z 54,80\% w 2004 r.). Drugim co do wielkości nośnikiem energii odnawialnej jest woda, udział energii wody w całkowitej produkcji energii ze źródeł odnawialnych wynosił w $2012 \mathrm{r}$. $16,11 \%$. Wciąż najmniej energii ze źródeł odnawialnych pochodzi z energii słońca - tylko 5,12\% w 2012 r. Zauważyć jednak należy, że w latach 2004-2012 nastąpił największy wzrost (ponad siedmiokrotny, z 0,62\% w 2004 r.) udziału tego nośnika w całkowitej produkcji energii ze źródeł odnawialnych. Ponad dwukrotnie w stosunku do 2004 r. zwiększył się udział energii wiatru w całkowitej produkcji energii ze źródeł odnawialnych (udział ten w 2004 r. wynosił 4,55\%, zaś w 2012 r. 9,95\%) oraz udział biogazu (w 2004 r. wynosił on 3,23\%, zaś w 2012 r. 6,80\%).

Na podstawie dostępnych danych przeprowadzono grupowanie państw Unii Europejskiej. Kraje grupowane były ze względu na udział produkcji energii odnawialnej z takich nośników energii, jak: woda, wiatr, słońce, biopaliwa stałe, biogaz oraz pozostałe (wśród nich m.in.: odpady komunalne, biobenzyna, biodiesel, energia geotermalna, energia pływów oceanu) w produkcji energii ogółem. 


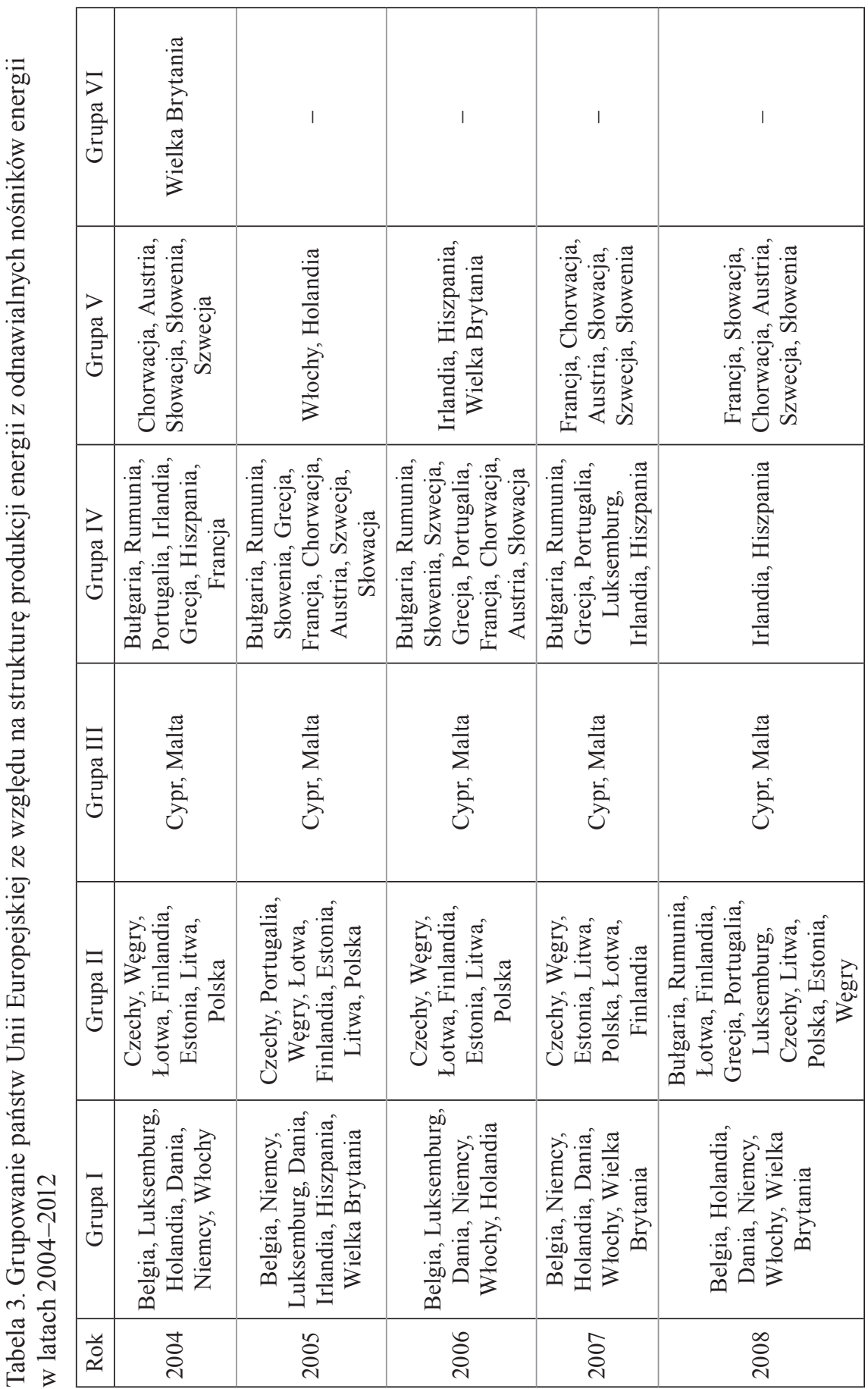




\begin{tabular}{|c|c|c|c|c|}
\hline 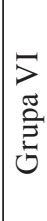 & 1 & 1 & 1 & 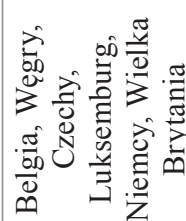 \\
\hline 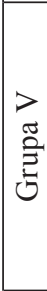 & 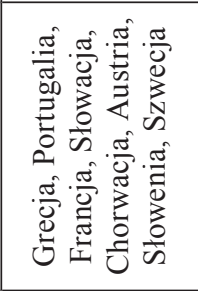 & 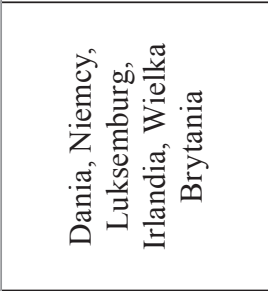 & 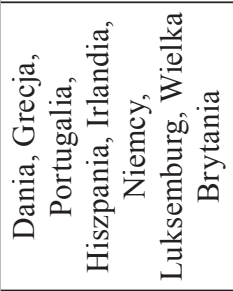 & 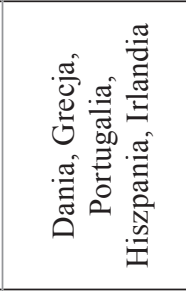 \\
\hline 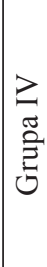 & 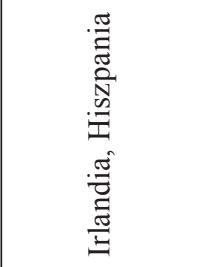 & 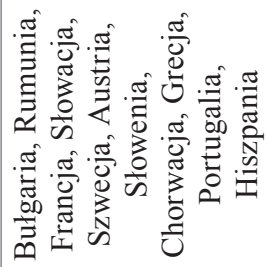 & 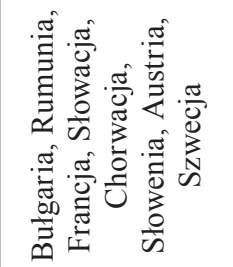 & 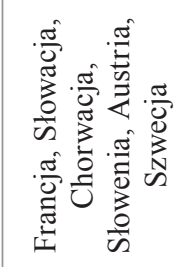 \\
\hline 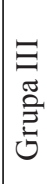 & 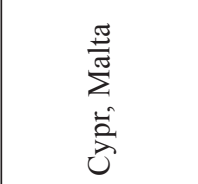 & $\stackrel{\vec{c}}{\vec{c}}$ & 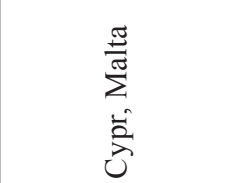 & \\
\hline 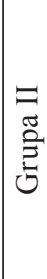 & 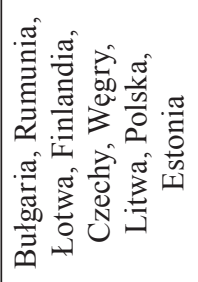 & 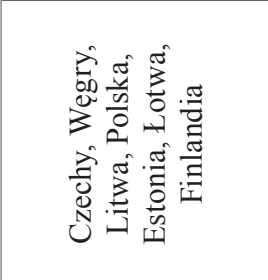 & 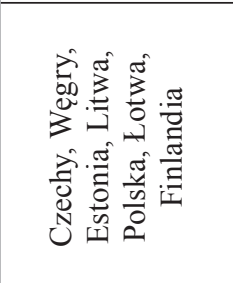 & 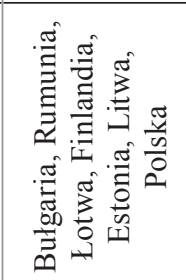 \\
\hline 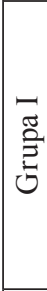 & 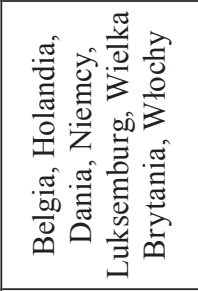 & 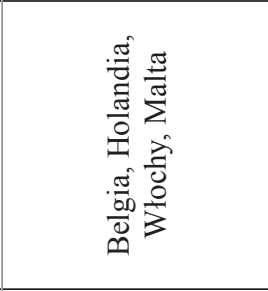 & 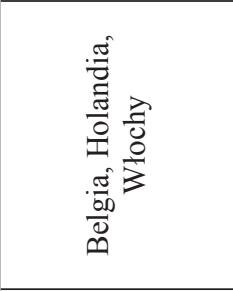 & 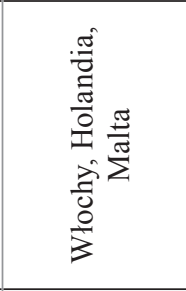 \\
\hline$\frac{\breve{y}}{\mathscr{O}}$ & \&ें & $\stackrel{\circ}{\stackrel{0}{\circ}}$ & $\overline{\bar{\sigma}}$ & $\stackrel{ }{\circ}$ \\
\hline
\end{tabular}


Zmienne poddane zostały normalizacji z wykorzystaniem przekształcenia ilorazowego z parametrami stałymi w czasie. Grupowanie przeprowadzono ${ }^{2}$ metodą Warda $^{3} \mathrm{z}$ wykorzystaniem odległości Euklidesa ${ }^{4}$. Liczbę grup ustalono, analizując wartości współczynnika sylwetkowego ${ }^{5}$.

Grupa I to kraje charakteryzujące się dużym udziałem produkcji energii odnawialnej z biopaliw w produkcji energii ogółem; wśród tych krajów są także takie, które w znacznym stopniu korzystają z energii wiatru, a największy odsetek produkcji pochodzi z pozostałych źródeł energii. Są to kraje, w których udział produkcji energii z odnawialnych źródeł energii (OZE) w produkcji energii ogółem przyjmuje wartości poniżej średniej dla Unii Europejskiej. W grupie tej następowały największe zmiany w badanym okresie, ale zwykle należały do niej takie państwa, jak Belgia i Holandia.

Grupa II to kraje korzystające niemal tylko z biopaliw. Są to państwa, w których udział produkcji energii z OZE w produkcji energii ogółem jest wysoki. Do tej grupy należała m.in. Estonia, jeden z krajów, w którym już w 2012 r. osiągnięty został cel na 2020 r. Do grupy II należały także niezmiennie: Polska, Czechy, Węgry, Łotwa, Finlandia i Litwa.

Cypr oraz na ogół Malta tworzyły grupę III, charakteryzującą się największym wykorzystaniem energii słońca, zaś udział produkcji energii z OZE w produkcji energii ogółem jest najniższy wśród krajów Unii Europejskiej.

Do grupy IV należały na ogół takie kraje, jak Bułgaria, Rumunia, Szwecja i Grecja. Charakterystyczne w tej grupie jest to, że najwięcej energii odnawialnej pochodzi z biopaliw i energii wody. Państwa należące do grupy IV to państwa z najwyższym udziałem produkcji energii z OZE w produkcji energii ogółem w UE.

Grupa V obejmowała kraje z dużym udziałem produkcji energii z OZE, przy czym energia ta pochodzi głównie $\mathrm{z}$ wody i biopaliw. W grupie tej na ogół znajdowała się Chorwacja i Austria.

Grupa VI, która została wyodrębniona w 2004 i 2012 r., to kraje, gdzie energia odnawialna w znacznej części pochodzi z biogazu, ale udział energii pochodzącej z OZE w końcowym zużyciu energii jest niewysoki.

2 Obliczenie przeprowadzono z wykorzystaniem pakietu Statistica.

${ }^{3}$ Ze względu na małą liczbę krajów zdecydowano się na metodę aglomeracyjnego grupowania hierarchicznego. Budując dendogram, uzyskano dobry obraz struktury grupowej.

${ }^{4}$ Zastosowano odległość euklidesową jako najczęściej wykorzystywaną odległość w przypadku danych mierzonych na skali przedziałowej i ilorazowej. Wyniki grupowania z wykorzystaniem kwadratu odległości euklidesowej były analogiczne.

5 Współczynnik sylwetkowy (indeks silhouette) zaprezentowany został w pracy [Kaufmann i Rousseeuw 1990]. Wybiera się liczbę skupień, dla której wartość współczynnika była największa. 


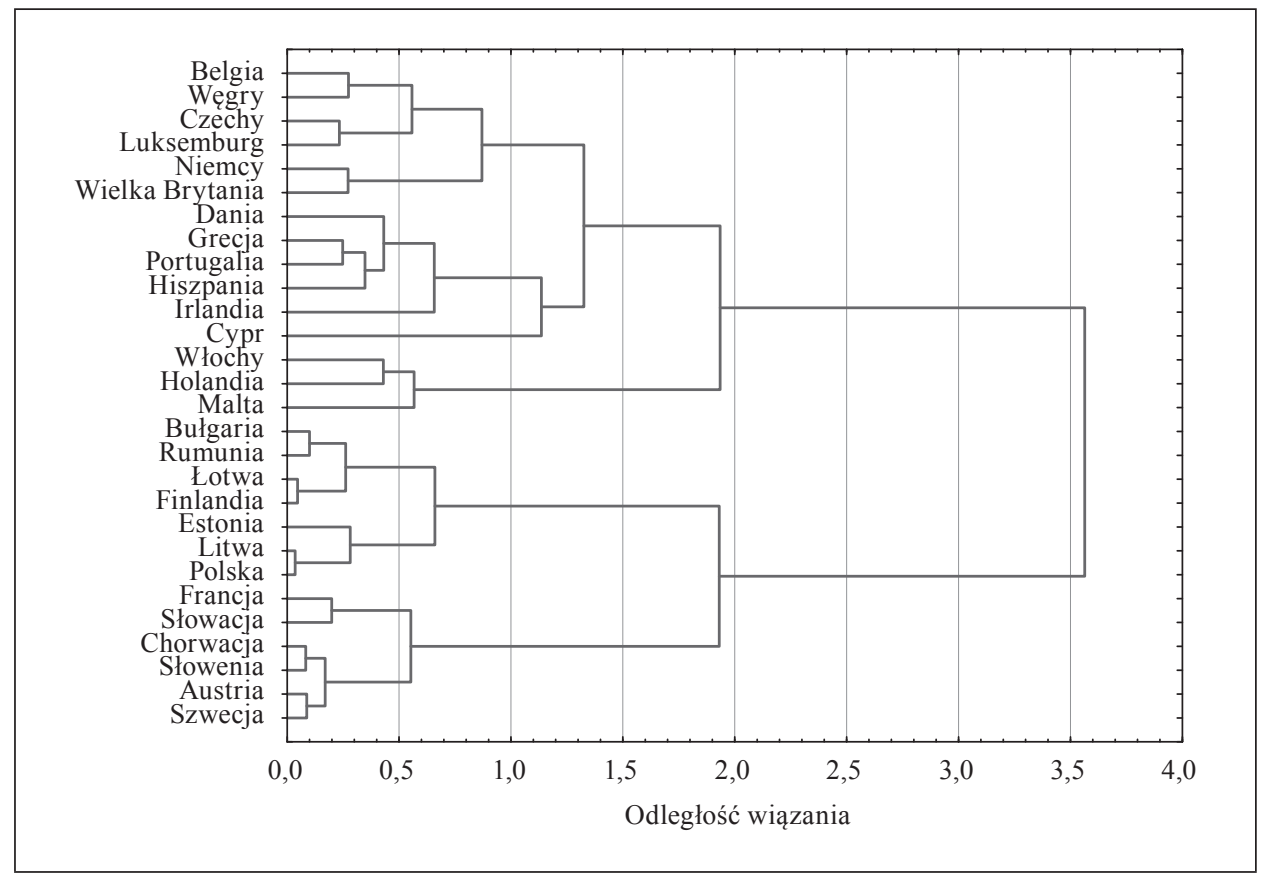

Rys. 6. Wyniki grupowania państw Unii Europejskiej ze względu na poszczególne nośniki energii odnawialnej w 2012 r.

Źródło: opracowanie własne.

Podobieństwo wyników podziałów klas zbadano, wykorzystując miarę skonstruowaną przez W.M. Randa (za: [Walesiak 2005]):

$$
R=\frac{Z}{\left(\begin{array}{l}
n \\
2
\end{array}\right)},
$$

gdzie:

$$
Z=\left(\begin{array}{l}
n \\
2
\end{array}\right)+\sum_{s=1}^{u} \sum_{r=1}^{v} n_{s r}^{2}-\frac{1}{2}\left(\sum_{s=1}^{u} n_{s \bullet}^{2}+\sum_{r=1}^{v} n_{\bullet r}^{2}\right)
$$

przy czym $u, v$ to liczby klas w porównywanych podziałach $P^{(q)}=\left\{P_{1}^{(q)}, \ldots, P_{u}^{(q)}\right\}$, $P^{(t)}=\left\{P_{1}^{(t)}, \ldots, P_{v}^{(t)}\right\} ; s=1, \ldots, u ; r=1, \ldots, v ; n_{s r}$ to liczba obiektów, które jednocześnie należą do klas $P_{s}^{(q)} \mathrm{i} P_{r}^{(t)} ; n_{\bullet r}-$ liczba obiektów w klasie $P_{r}^{(t)} ; n_{s}-$ liczba obiektów w klasie $P_{s}^{(q)}$. 
Miarę tę interpretuje się jako odsetek par obiektów zgodnych w obu klasyfikacjach (w przypadku prowadzonej analizy w wybranych dwóch latach) w ogólnej liczbie par obiektów określonych na zbiorze. Wartość 0 oznacza, że podziały są zupełnie niepodobne, zaś wartość 1 oznacza podziały identyczne.

Tabela 4. Miara podobieństwa składów klas

\begin{tabular}{|c|c|c|c|c|c|c|c|c|}
\hline Rok & 2005 & 2006 & 2007 & 2008 & 2009 & 2010 & 2011 & 2012 \\
\hline 2004 & 0,83 & 0,90 & 0,90 & 0,82 & 0,87 & 0,85 & 0,85 & 0,79 \\
\hline 2005 & $\times$ & 0,90 & 0,81 & 0,80 & 0,84 & 0,89 & 0,90 & 0,74 \\
\hline 2006 & $\times$ & $\times$ & 0,84 & 0,80 & 0,90 & 0,92 & 0,88 & 0,72 \\
\hline 2007 & $\times$ & $\times$ & $\times$ & 0,85 & 0,84 & 0,81 & 0,85 & 0,75 \\
\hline 2008 & $\times$ & $\times$ & $\times$ & $\times$ & 0,88 & 0,75 & 0,78 & 0,75 \\
\hline 2009 & $\times$ & $\times$ & $\times$ & $\times$ & $\times$ & 0,84 & 0,81 & 0,78 \\
\hline 2010 & $\times$ & $\times$ & $\times$ & $\times$ & $\times$ & $\times$ & 0,89 & 0,72 \\
\hline 2011 & $\times$ & $\times$ & $\times$ & $\times$ & $\times$ & $\times$ & $\times$ & 0,77 \\
\hline
\end{tabular}

Źródło: obliczenia własne.

Jak wynika z tabeli 4, podziały w kolejnych latach są do siebie bardzo podobne. Najmniejsze wartości miernika zaobserwować można dla 2012 r., ale nawet tutaj udział par zgodnych w stosunku do podziałów z lat wcześniejszych wynosi ponad $70 \%$.

\section{Wnioski}

Największy udział energii ze źródeł odnawialnych w ogólnym zużyciu energii odnotowano w Szwecji, a najmniejszy na Malcie. We wszystkich krajach Unii Europejskiej w badanym okresie nastąpił wzrost tego udziału - największy na Malcie (jest to kraj, który ma najniższy cel do osiągnięcia, ale mimo to wciąż brakuje niemal 9 pkt proc.), wysokim wzrostem tego udziału charakteryzują się także: Belgia, Wielka Brytania, Luksemburg i Irlandia (tu wzrost wyniósł ponad $300 \% \mathrm{w}$ stosunku do 2004 r.). Najmniejszy wzrost zaobserwować można m.in. na Łotwie (jest to państwo, które już w 2012 r. zrealizowało cel na 2020 r.) i w Finlandii (do realizacji celu brakuje jeszcze 4 pkt proc.).

Jak wynika z analizy wartości współczynnika tau-Kendalla, uporządkowania krajów ze względu na udział energii odnawialnej w końcowym zużyciu energii w kolejnych latach są niemal identyczne. 
Z analizy miernika Randa, który określa podobieństwo składów klas, wynika że rezultaty grupowania wybranych krajów Unii Europejskiej ze względu na strukturę produkcji energii elektrycznej z odnawialnych nośników energii w latach 2004-2012 nie różnią się znacząco między sobą. Grupy utworzone w poszczególnych latach są mniej więcej stałe i dość jednorodne. Kraje należące do poszczególnych grup mają bardzo podobną strukturę nośników energii odnawialnej, która w kolejnych latach nie ulega znaczącym zmianom. Ponadto są to państwa o podobnym udziale energii odnawialnej w końcowym zużyciu energii. W badanym okresie Polska należała do grupy państw, w której głównym źródłem energii odnawialnej są biopaliwa i energia wody (grupa II).

W toku są dalsze badania związane z energią ze źródeł odnawialnych, które dotyczyć będą źródeł finansowania energii ze źródeł odnawialnych oraz zależności między poziomem rozwoju poszczególnych krajów a udziałem energii ze źródeł odnawialnych w końcowym zużyciu energii.

\section{Literatura}

Badyda K. [2013], Energetyka wiatrowa. Aktualne trendy rozwoju w Polsce, „Energetyka", nr 5/2013.

Czechowicz Z. [2012], Rozproszone źródła energii elektrycznej ze szczególnym uwzględnieniem odnawialnych źródet energii, „Energetyka” nr 2/2012.

Dyrektywa 2009/28/WE z dnia 23 kwietnia 2009 r. w sprawie promowania stosowania energii ze źródeł odnawialnych zmieniająca i w następstwie uchylająca dyrektywy 2001/77/WE oraz 2003/30/WE, Dz.Urz. UE, L 140/16, 5.06.2009.

Energia odnawialna $w$ Polsce $w 2012$ [2012], http://gramwzielone.pl/uploads/files/ ENERGIA\%20ODNAWIALNA\%20W\%20POLSCE\%202012_10_21.pdf.

Energia ze źródet odnawialnych w 2012 r. [2013], Główny Urząd Statystyczny, Warszawa.

Karpińska M., Dul Ł. [2014], Kierunki polityki energetycznej Polski oraz Unii Europejskiej w latach 2007-2030, „Energetyka”, nr 3/2014.

Kaufmann L., Rousseeuw P.J. [1990], Finding Groups in Data: An Introduction to Cluster Analysis, Wiley, New York.

Sadowski T., Świderski G., Lewandowski W. [2008], Wykorzystanie odnawialnych i nieodnawialnych źródet energii w Polsce $i$ w krajach UE, „Energetyka”, nr 4/2008.

Walesiak M. [2005], Rekomendacje w zakresie strategii postępowania $w$ procesie klasyfikacji zbioru obiektów [w:] Przestrzenno-czasowe modelowanie i prognozowanie zjawisk gospodarczych, red. A. Zeliaś, Wydawnictwo Akademii Ekonomicznej w Krakowie, Kraków.

Walesiak M. [2006], Uogólniona miara odległości w statystycznej analizie wielowymiarowej, wyd. drugie rozszerzone, Wydawnictwo Akademii Ekonomicznej im. Oskara Langego we Wrocławiu, Wrocław. 


\title{
The Market of Renewable Energy Sources in the European Union - a Statistical Analysis
}

\author{
(Abstract)
}

The ongoing dynamic development of civilization has translated into growing demand for energy. The use of traditional energy sources such as coal, oil and natural gas is not only associated with an increase in pollution, but also causes the depletion of natural resources. Renewable sources of energy are an alternative to non-renewable energy sources such as fossil fuels.

The main aim of this article is to assess the changes occurring in the market of renewable energy in the European Union. Based on available data, countries were ordered linearly, according to the share of energy from renewable sources they used to produce electricity. Changes in how energy from renewable sources is obtained are discussed. The countries were classified according to how they obtained energy from renewable sources.

Keywords: renewable energy, linear ordering, classified, Kendall tau coefficient, Rand index. 